ISSN 0258-7122

Bangladesh J. Agril. Res. 35(3) : 423-429, September 2010

\title{
SURVEY ON MAJOR DISEASES OF VEGETABLE AND FRUIT CROPS IN CHITTAGONG REGION
}

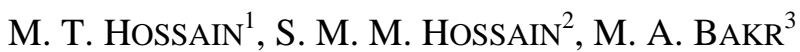 \\ A. K. M. MATIAR RAHMAN ${ }^{4}$ AND S. N. UDDIN ${ }^{5}$
}

\begin{abstract}
A survey was conducted during October 2006 to June 2008 to observe disease prevalence of vegetable and fruit crops in Chittagong region. Through the survey, 24 diseases with their incidence and severity were recorded. The average higher leaf infection in early blight of potato and fruit infection in soft rot of potato were recorded $37 \%$ and $39 \%$, respectively. The highest leaf infection (43\%) of early blight of tomato that was more frequented (mode) $36 \%$ in different locations with $\pm 0.45 \%$ ranges (Standard error) for causing the disease as recorded at Sadar Anwara upazila of Chittagong. The highest fruit infection of soft rot of potato (43\%) was recorded at Dohazari, Chandanaish upazila in Chittagong. The average of higher disease severity of leaf (27\%) and fruit (33\%) was recorded in early blight of tomato and soft rot of potato, respectively, and the highest disease severity of leaf (29\%) and fruit (35\%) was recorded in Phomopsis blight and early blight of tomato and soft rot of potato, respectively.
\end{abstract}

Keywords : Diseases, vegetable, fruit, survey.

\section{Introduction}

Bangladesh is an agrarian country. Its economy is mainly dependent on agriculture. Crop loss owing to the diseases poses a great threat to Bangladesh agriculture. More than 454 diseases in around 100 cultivated crops have so far been recorded in Bangladesh (Anon., 2006). The diseases cause substantial losses to crops. These enormous losses hamper the total yield production of the country.

Generally, 30-50\% loss is incurred due to the disease (Khan, 1999). Approximately $15-20 \%$ in general and $30-50 \%$ in severe case of fruit rots of eggplant is caused seriously due to the Phomopsis vexans (Das, 1998; Khan. 1999) and about 80 million taka is lost by this disease (Anon., 2003). The magnitude of yield loss depends upon the intensity of the disease. The amount of crop and fruit losses owing to a particular disease varied from place to place because of the existence of different races, biotypes, or strains of the pathogen (Sastry and Hegde, 1989). Chittagong region includes hilly district of

\footnotetext{
${ }^{1}$ Scientific Officer, ${ }^{2}$ Senior Scientific Officer, ${ }^{4}$ Chief Scientific Officer, Regional Agricultural Research Station, Bangladesh Agricultural Research Institute (BARI), Hathazari, Chittagong, ${ }^{3}$ Project Director, Strengthening of Pulses and Oilseed Research Programmes in Bangladesh, ORC, Bangladesh Agricultural Research Institute (BARI), ${ }^{5}$ Horticulturist, Horticulture Centre, DAE, Hathazari, Bangladesh..
} 
Bangladesh, the hilly areas of Chittagong fall under the agro-ecological zone number 29. Agroclimatic conditions of the region is different from the other parts of the country. Very little survey on disease of vegetables and fruits was done previously in Chittagong region. Only at Dohazari, 60\% eggplant infection and 20\% fruit infection owing to Phoinopsis vexans were recorded (Meah, 2007). In view of above facts, the present study was undertaken to survey the information on incidence and severity of the diseases of vegetable and fruit crops in Chittagong region of Bangladesh.

\section{Materials and Method}

The survey was conducted in Chittagong region during October 2006 to June 2008. The incidence and severity of different diseases were recorded. Disease assessments were done in 1000 farmers' fields in 10 locations of 10 upazilas of Chittagong regions. The study areas were Mirjapur, Hathazari, Nazirhat, Fatikchury, Amilaish, Satkania: Dhol ghat, Patia, Sadar, Anara, Binajuri. Raozan, Ranirhat, Rangunia, Oyahedpur, Mirshary, Harabkunda, Sitakunda, and Dohazari, Chandanaish. In every area, 100 plants of vegetables and fruits were evaluated in the farmers' fields. Diseases were recorded in Kharif and Rabi seasons both on leaf and fruit. The incidence and severity data were the mean value of leaf and fruit infection of two years' assessment. Data were expressed in percentage. The formula in calculating the disease incidence and severity is:

$\%$ Leaf $/$ fruit infection $=\frac{\text { Number of Leaves } / \text { Fruit infected } \times 100}{\text { Total Number of leaves } / \text { Fruit counted }}$

PDI for severity $=\frac{\text { Sum of all disease ratings } \times 100}{\text { Total number of leaves/fruits } \times \text { maximum rating value }}$

For estimation of leaf and fruit area diseased, the whole fruit and leaf surface area vas considered as 100 and thereby the infected area was determined by eye estimation for Percent of Disease Index (PDI), i.e. severity. By the scale of Islam et al. (1990) for Phomopsis blight, Nene et al. (1982) for sclerotium wilting. Anon. (1974) for early blight of tomato, Saha, (2001) for white rust and anthracnose of amaranthus and chili and Alternaria blight for radish, Goncalves et al., (1997) for leaf spot and rust for bean and anthracnose of mango, Anon. (2001) for sigatoka of banana, Kader and Ranhman (2001) for anthracnose of guava and Anon. (2008) for measuring the PDI of other diseases were maintained properly. Anthracnose of papaya and banana, stem-end rot of mango and soft rot of potato diseases were evaluated in post harvest condition collected from local market of Hathazari and Reazuddin Bazar of Chittagong. Data were analyzed for descriptive statistics, such as mean, mode, standard deviation, and standard error following Microsoft Excel package program. 


\section{Results and Discussion}

Incidence and severity are the tools for measuring the diseases. Twenty four diseases were recorded in Chittagong region. The highest leaf incidence (43\%) as recorded from the early blight of tomato at Sadar Anawara upazila followed by early blight of potato (41\%) at Dohazari. Chandanaish and Phomopsis blight (39\%) in Dhol ghat, Patia upazila. The average of $37 \%$ in early blight of tomato

Table 1. Disease incidence on leaf of vegetable and frits at different locations of Chittagong.

\begin{tabular}{|c|c|c|c|c|}
\hline Name of the disease & Mean & Mode & Sd & Se $( \pm)$ \\
\hline Phomopsis blight of eggplant & 35 & 35 & 3.50 & 0.35 \\
\hline Early blight of tomato & 37 & 36 & 4.32 & 0.43 \\
\hline Alternaria blight of cabbage & 25 & 26 & 2.40 & 0.24 \\
\hline Early blight of potato & 37 & 37 & 2.45 & 0.25 \\
\hline Soft rot of potato & - & & - & - \\
\hline White rust of amarnathus & 14 & 14 & 2.45 & 0.25 \\
\hline Anthracnose of amarnathus & 15 & 15 & 3.05 & 0.31 \\
\hline Anthracnose of chili & 14 & 14 & 1.15 & 0.12 \\
\hline Alternaria blight of radish & 22 & 22 & 2.83 & 0.28 \\
\hline Cercospora leaf spot of bean & 24 & 24 & 1.63 & 0.16 \\
\hline Rust of bean & 27 & 27 & 3.09 & 0.31 \\
\hline Anthracnose of bottle gourd & 11 & 11 & 0.94 & 0.09 \\
\hline Alternaria blight of cauliflower & 21 & 21 & 1.76 & 0.18 \\
\hline Cercospora leaf spot of spinach & 24 & 24 & 1.76 & 0.18 \\
\hline Anthracnose of mango & 25 & 25 & 1.15 & 0.12 \\
\hline Stem-end rot of mango & - & - & - & - \\
\hline Anthracnose of guava & 26 & 26 & 1.76 & 0.18 \\
\hline Anthracnose of litchi & 19 & 19 & 2.00 & 0.20 \\
\hline Rhizopus rot of jackfruit & - & - & - & - \\
\hline Anthracnose of papaya & - & - & - & - \\
\hline Scab of lemon & 11 & 11 & 0.94 & 0.09 \\
\hline Sigatoka of banana & 24 & 24 & 1.15 & 0.12 \\
\hline Panama of banana & 19 & 19 & 1.33 & 0.13 \\
\hline Anthracnose of banana & - & - & - & - \\
\hline
\end{tabular}

Note: $\mathrm{Sd}=$ Standard deviation, $\mathrm{Se}=$ Standard Error .

and early blight of potato was recorded. The deviation of the disease incidence of early blight of tomato and early blight of potato was $4.32 \%$ and $2.45 \%$, 
respectively. More frequency (mode) of the early blight of tomato and early blight of potato was $36 \%$, and $37 \%$, respectively, at different locations. Besides, the lowest leaf incidence (9\%) was observed on the scab of lemon in Sadar Anwara upazila followed by anthracnose of bottle gourd at different locations (Mirjapur, Hathazari; Sadar Anwara; Ranirhat, Rangunia; Barabkunda. Sitakuiida; Dohazari Chandanaish), anthracnose of chilli and white rust in Mirjapur. Hathazari and Barahkunda, Sitakunda. The average of leaf incidence was $11 \%$ as detected in scab of lemon and anthracnose of bottle gourd. The standard deviation of the scab of lemon was 0.94 of the disease (Table 1).

Table 2. Disease incidence on fruit in vegetable and frits at different locations of Chittagong.

\begin{tabular}{llllll}
\hline \multicolumn{1}{c}{ Name of the disease } & \multicolumn{1}{c|}{ Mean } & \multicolumn{1}{c|}{ Mode } & \multicolumn{1}{c}{ Sd } & \multicolumn{1}{c}{ Se \pm ( $)$} \\
\hline Phomopsis blight of eggplant & 33 & 36 & 4.16 & 0.42 \\
Early blight of tomato & 37 & 30 & 2.98 & 0.30 \\
Alternaria blight of cabbage & - & - & - & - \\
Early blight of potato & 37 & 27 & 1.63 & 0.16 \\
Soft rot of potato & 39 & 39 & 2.45 & 0.25 \\
White rust of amarnathus & - & - & - & - \\
Anthracnose of amarnathus & - & - & - & - \\
Anthracnose of chili & 22 & 21 & 2.26 & 0.23 \\
Alternaria blight of radish & - & - & - & - \\
Cercospora leaf spot of bean & 22 & 22 & 2.16 & 0.22 \\
Rust of bean & 12 & 11 & 1.05 & 0.11 \\
Anthracnose of bottle gourd & 15 & 15 & 0.94 & 0.09 \\
Alternaria blight of cauliflower & - & - & - & - \\
Cercospora leaf spot of spinach & - & - & - & - \\
Anthracnose of mango & 23 & 23 & 1.94 & 0.19 \\
Stem-end rot of mango & 16 & 16 & 1.33 & 0.13 \\
Anthracnose of guava & 27 & 27 & 2.36 & 0.24 \\
Anthracnose of Litchi & 20 & 20 & 2.16 & 0.22 \\
Rhizopus rot of jack fruit & 24 & 25 & 2.11 & 0.21 \\
Anthracnose of papaya & 12 & 12 & 0.82 & 0.08 \\
Scab of lemon & 17 & 17 & 2.31 & 0.23 \\
Sigatoka of banana & - & - & - & - \\
Panama of banana & - & - & - & - \\
Anthracnose of banana & 13 & 13 & 4.29 & 0.43 \\
\hline Not Sd Stat & - & &
\end{tabular}

Note: $\mathrm{Sd}=$ Standard deviation, $\mathrm{Se}=$ Standard Error . 
The highest disease incidence (43\%) was recorded from soft rot of potato in Dohazari Chandanaish upazila followed by Phomopsis blight (39\%) in Barabkunda. Sitakunda upazila. The 1owest fruit disease incidence (11\%) was recorded from anthracnose of banana (Nazirhat, Fatikchur). anthracnose of papaya (Nazirhat, Fatikchury; Sadar Anwara, Ranirhat. Rangunia) followed by anthracnose of bottle gourd (14\%) in Amilaish, Satkania; Binajuri, Raozan and Oyahedpur, Mirshary. The average higher fruit disease incidence (39\%) was recorded from the soft rot of potato which deviated $2.45 \%$ among different locations with ranges $\pm 0.25 \%$ for causing diseases (Table 2 ).

Table 3. Disease Severity (PDI) on leaf in vegetable and frits at different locations of Chittagong.

\begin{tabular}{|c|c|c|c|c|}
\hline Name of the disease & Mean & Mode & Sd & Se $( \pm)$ \\
\hline Phomopsis blight of eggplant & 25 & 25 & 2.16 & 0.22 \\
\hline Early blight of tomato & 27 & 27 & 1.56 & 0.16 \\
\hline Alternaria blight of cabbage & 25 & 25 & 1.49 & 0.15 \\
\hline Early blight of potato & 26 & 26 & 1.15 & 0.12 \\
\hline Soft rot of potato & - & - & - & - \\
\hline White rust of amarnathus & 15 & 14 & 1.05 & 0.11 \\
\hline Anthracnose of amarnathus & 13 & 13 & 1.15 & 0.12 \\
\hline Anthracnose of chili & 10 & 10 & 0.82 & 0.08 \\
\hline Alternaria blight of radish & 18 & 18 & 1.15 & 0.12 \\
\hline Cercospora leaf spot of bean & 21 & 21 & 1.15 & 0.12 \\
\hline Rust of bean & 15 & 14 & 1.05 & 0.11 \\
\hline Anthracnose of bottle gourd & 12 & 12 & 1.15 & 0.12 \\
\hline Alternaria blight of cauliflower & 18 & 18 & 1.15 & 0.12 \\
\hline Cercospora leaf spot of spinach & 22 & 21 & 1.05 & 0.11 \\
\hline Anthracnose of mango & 22 & 22 & 1.15 & 0.12 \\
\hline Stem-end rot of mango & - & - & - & - \\
\hline Anthracnose of guava & 25 & 25 & 1.15 & 0.12 \\
\hline Anthracnose of Litchi & 19 & 19 & 1.15 & 0.12 \\
\hline Rhizopus rot of jack fruit & - & - & - & - \\
\hline Anthracnose of papaya & - & - & - & - \\
\hline Scab of lemon & 13 & 13 & 1.41 & 0.14 \\
\hline Sigatoka of banana & 22 & 22 & 1.76 & 0.18 \\
\hline Panama of banana & 16 & 16 & 0.94 & 0.09 \\
\hline Anthracnose of banana & - & - & - & - \\
\hline
\end{tabular}

Note: $\mathrm{Sd}=$ Standard deviation, $\mathrm{Se}=$ Standard Error. 
On the contrary, the highest percent of disease index i. e. severity in leaf and fruit as $20 \%$ and $35 \%$, respectively, in case of Phomopsis blight of eggplant and early blight of tomato and early blight of potato. The lower severity of leaf and fruit was $11 \%$ as recorded from scab of lemon and anthracnose of bottle gourd. The higher average severity of leaf and fruit was $27 \%$ and $33 \%$, respectively, as recorded from early blight of tomato and soft rot of potato (Table 3 and 4).

Table 4. Disease severity (PDI) on fruit in vegetables and frits at different locations of Chittagong.

\begin{tabular}{llllll}
\hline \multicolumn{1}{c}{ Name of the disease } & \multicolumn{1}{c|}{ Mean } & \multicolumn{1}{c|}{ Mode } & \multicolumn{1}{c}{ Sd } & \multicolumn{1}{c}{ Se $( \pm)$} \\
\hline Phomopsis blight of eggplant & 23 & 22 & 2.40 & 0.24 \\
Early blight of tomato & 24 & 24 & 1.15 & 0.12 \\
Alternaria blight of cabbage & - & - & - & - \\
Early blight of potato & 22 & 22 & 1.15 & 0.12 \\
Soft rot of potato & 33 & 33 & 1.25 & 0.13 \\
White rust of amarnathus & - & - & - & - \\
Anthracnose of amarnathus & - & - & - & - \\
Anthracnose of chili & 15 & 15 & 1.15 & 0.12 \\
Alternaria blight of radish & - & - & - & - \\
Cercospora leaf spot of bean & 19 & 19 & 1.15 & 0.12 \\
Rust of bean & 11 & 11 & 1.15 & 0.12 \\
Anthracnose of bottle gourd & 13 & 14 & 1.33 & 0.13 \\
Alternaria blight of cauliflower & - & - & - & - \\
Cercospora leaf spot of spinach & - & - & - & - \\
Anthracnose of mango & 27 & 27 & 1.25 & 0.13 \\
Stem-end rot of mango & 22 & 22 & 1.94 & 0.09 \\
Anthracnose of guava & 27 & 27 & 1.41 & 0.14 \\
Anthracnose of Litchi & 18 & 18 & 0.94 & 0.09 \\
Rhizopus rot of jack fruit & 21 & 21 & 0.94 & 0.09 \\
Anthracnose of papaya & 17 & 17 & 1.05 & 0.11 \\
Scab of lemon & 15 & 15 & 1.41 & 0.14 \\
Sigatoka of banana & - & - & - & - \\
Panama of banana & - & - & - & - \\
Anthracnose of banana & 11 & 11 & 1.15 & 0.12 \\
\hline
\end{tabular}

Note: $\mathrm{Sd}=$ Standard deviation, $\mathrm{Se}=$ Standard Error.

Sometimes, the disease information of the study on incidence and severty agreed with the reviewed literature. According to Das (1998), about 15-20\% in general and $30-50 \%$ in severe case of fruit rots of eggplant were caused seriously due to Phomopsis blight. It was mostly similar to the record of study against the disease in the study areas. But, no detailed research findings on disease records were done keenly in Chittagong regions previously. Only at Dohazari 60\% plant 
infection and 20\% fruit infection owing to Pliomopsis vexams was recorded in Chittagong region (Meah, 2007). Sastry and Hegde (1989) stated that the amount of crop and fruit losses to a particular disease varied from place to place because of the existence of. different races, biotypes, or strains of the pathogen. So, the incidence and severity of vegetables and fruits can differ in the different locations of Chittagong.

\section{References}

Anonymous. 2008. Rating scale and severity index of crop diseases. Bangladesh Phytopathological Society, Plant Pathology Division, Bangladesh Agricultural Research Institute, pp. 1.31.

Anonymous. 2006. Annual Report (2004-2005). Plant Pathology Division, Bangladesh Agricultural Research Institute, Gazipur.

Anonymous. 2003. The Daily Ittefaq, $5^{\text {th }}$ February, p. 19, Col-1.

Anonymous. 2001. Training course on International Musa Testing programme (IMTP) held on 18-22 June 2001. Kuala Lumpur, Malaysia.

Anonymous. 1974. Annual report. Asian Vegetable Research and Development Centre, pp. 57-59.

Das, B. H. 1998. Studies on Phomopsis in the fruit of brinjal. An M. S. Thesis submitted to the Department of Plant Pathology, Bangladesh Agricultural University, Mymensingh. pp. 33-44.

Gonealves-Vidigal, M. C. Antonio A. Cardose, Clibas Vieira and S. Saraiva Luiz. 1997. Inheritance of anthracnose resistance in common bean genotypes. Braz. J. Gent. v. 20 n. 1: P. I. 207262 and $A B 136$.

Khan, N. U. 1999. Studies on epidemiology, seed-borne nature and management of Phomopsis fruit rot of brinjal. An MS thesis submitted to the Department of Plant Pathology, Bangladesh Agricultural University, Mymensingh. pp. 25-40.

Islam, S.K., P. Sintansu, and S. Pan. 1990. Effect of humidity and temperature on Phomopsis fruit rot of brinjal. Environment and Ecology 8(4): 1309-1310.

Meah, M. B. 2007. Development of an integrated approach for management of Phomopsis blight and fruit rot of eggplant in Bangladesh. Final research report (2001-2006). 102 pp. Department of Plant Pathology, Bangladesh Agricultural University, Mymensingh, Bangladesh.

Nene, Y. L., M. P. Haware and M. Natarajan. 1982. Proc. Intl. Workshop on Chickpea Improvement, held at ICRISAT, Patancheru, Andhra Pradesh, India. 96 pp.

Saha, S. R. 2001. Heat tolerance in sweat pepper (Capsicum annum L.), Ph. D. thesis submitted to Department of Horticulture, Bangabandhu Sheikh Mujibur Rahman Agril. University, Salna, Gazipur. 236 pp.

Sastry, M. N. L. and R. K. Hegde. 1989. Variability of Phytophthora species obtained from plantation of Karnataka. Indian Phytopath. 42(3): 421-425. 